\title{
Agglomeration in Stripper Ash Coolers and Its Possible Remedial Solutions: a Case Study
}

\author{
Ravi Inder Singh ${ }^{1}$
}

Received: 26 August 2014/ Accepted: 10 February 2016/Published online: 4 March 2016

(C) The Institution of Engineers (India) 2016

\begin{abstract}
The bottom ash of circulating fluidized bed (CFB) boiler contains large amounts of physical heat. When low quality coals are used in these types of boilers, the ash content is normally more than $40 \%$ and the physical heat loss is approximately $3 \%$ if the bottom ash is discharged without cooling. Bottom ash cooler (BAC) is often used to treat the high temperature bottom ash to reclaim heat, and to facilitate the easily handling and transportation of ash. The CFB boiler at BLA Power, Newari, MP (India) is facing problems of clinker formation in strip ash coolers of plant since the installation of unit. These clinkers are basically agglomerates, which leads to defluidization of stripper ash cooler (BAC) units. There are two strip ash coolers in unit. Each strip ash cooler is capable of working independently. The proper functioning of both strip coolers is very important as it is going to increase the combustion efficiency of boiler by stripping of fine unburnt coal particles from ash, which are injected into the furnace. In this paper causes, characterization of agglomerates, thermo gravimetric analysis of fuel used, particular size distribution of coal and sand and possible remedial solution to overcome these agglomerates in strip ash coolers has also been presented. High temperature in compact separators, non uniform supply of coal and not removing small agglomerates from stripper ash cooler are among main causes of agglomeration in stripper ash cooler. Control of compact separator temperature, replacing $10-12 \%$ of bed material and cleaning stripper ash cooler
\end{abstract}

Ravi Inder Singh

dr.rjassar@gmail.com

1 Birla Institute of Technology and Science, Pilani 333031, Rajasthan, India periodically will decrease agglomeration in stripper ash cooler of unit.

Keywords Defluidization - Stripper ash cooler · Coal · Particle size distribution

\section{Introduction}

Due to high heat transfer rate, high carbon utilizing efficiency, fuel flexibilities and other advantages, numerous circulating fluidized bed (CFB) boilers have grown up in India and across the world in the last decade. While the CFB incinerates the low-calorie fuel, the ash content is normally more than $40 \%$ and the physical heat loss is approximately $3 \%$, if the bottom ash is discharged without cooling. In addition, the red-hot bottom ash is bad for mechanical handling and transportation, as the upper limit temperature of the ash handling machinery is $200{ }^{\circ} \mathrm{C}$. Beyond $200{ }^{\circ} \mathrm{C}$, there is a cost implication of the equipment which handles these ash increases significantly. Discharging ash at higher temperature means significant amount of heat is wasted, that results in poor efficiency of equipment. Therefore, a bottom ash cooler (BAC) is often used to treat the high temperature bottom ash to reclaim heat, and to have the ash easily handled and transported. Due to very high velocity in CFB, if BAC does not work the efficiency of circulating fluidized boiler will reduce sharply. The efficiency of whole unit will be very low as the heat added to the system is not fully reclaimed. It is due to fact that fines present in ash will not burn and it will be discharged to atmosphere if ash cooler is not used. BAC is a key auxiliary device of CFB boilers and it has direct influence on performance economic operation of the boiler as it is used in reclaiming heat from unit. There are many 
kinds of BACs equipped for large-scale CFB boilers with the continuous development and improvement of the CFB boiler. These ash coolers are water cooled ash cooling, screw type, rolling-cylinder ash cooler (RAC), fluidized bed ash cooler (FBAC).

In the fluidized bed ash cooler, the ash is cooled and stripped of coal fines, which is later reinjected into furnace to improve efficiency. The heavier agglomerates particles are cooled with air and water, which are later removed. Bed ash is removed with rotary valve from strip cooler. The fluidized bed ash cooler is fluidized with fluidizing air. Any heavier particle greater than recommended size may hamper its fluidization. Agglomeration i.e. clinker formation in riser, loop seal leg and stripper ash coolers is one of problem CFB industry is facing. In this paper case study of fluidized bed ash cooler of 45 MW CFBC plant has been done, which is situated at Newari, Madhya Pradesh, India.

\section{Description of Problem}

The CFB of this company is having unique design. The water cooler compact separator, having pig tale nozzles in the bed and directional nozzles in strip ash cooler are important features of this design. The block diagram of fluidized bed ash cooler is shown in Fig. 1. The location of compact separator used in CFB at the plant site and location of fluidized bed ash coolers and loop seals in CFB at the plant is also shown in Fig. 1. Solids separation system is a key element of any CFB boiler design, influencing both capital and operating costs.

It is quite important to prevent the formation of clinkers in CFB boilers for stable and continuous operation of strip ash coolers. The clinker, an agglomerate form of some mineral matters, is in general one of the fundamental problems in CFB boilers(particular for biomass fuels) leads to the possibilities of the instability of fluidization and the decrease of boiler utilization. Especially, poor fluidization due to the clinker formation may finally result in the complete defluidization of the stripper cooler, which means an unscheduled shutdown of the stripper ash cooler. The defluidization of strip ash cooler is not reported on all days ever since the unit has started. Either right hand side or left hand side strip cooler is not working properly since the installation of boiler. Defluidization of stripper results severally affects the working of the unit. Non operation of fluidized bed ash cooler strictly leads of poor combustion efficiency of system as coal fines are not stripped of from ash. The loss of efficiency/performance could be represented as Loss on ignition in the CFB/BFB units. Table 1 shows the loss on ignition numbers for bed drain from stripper ash cooler.
Fig. 1 Location of compact separators, loop seals and fluidized bed ash coolers

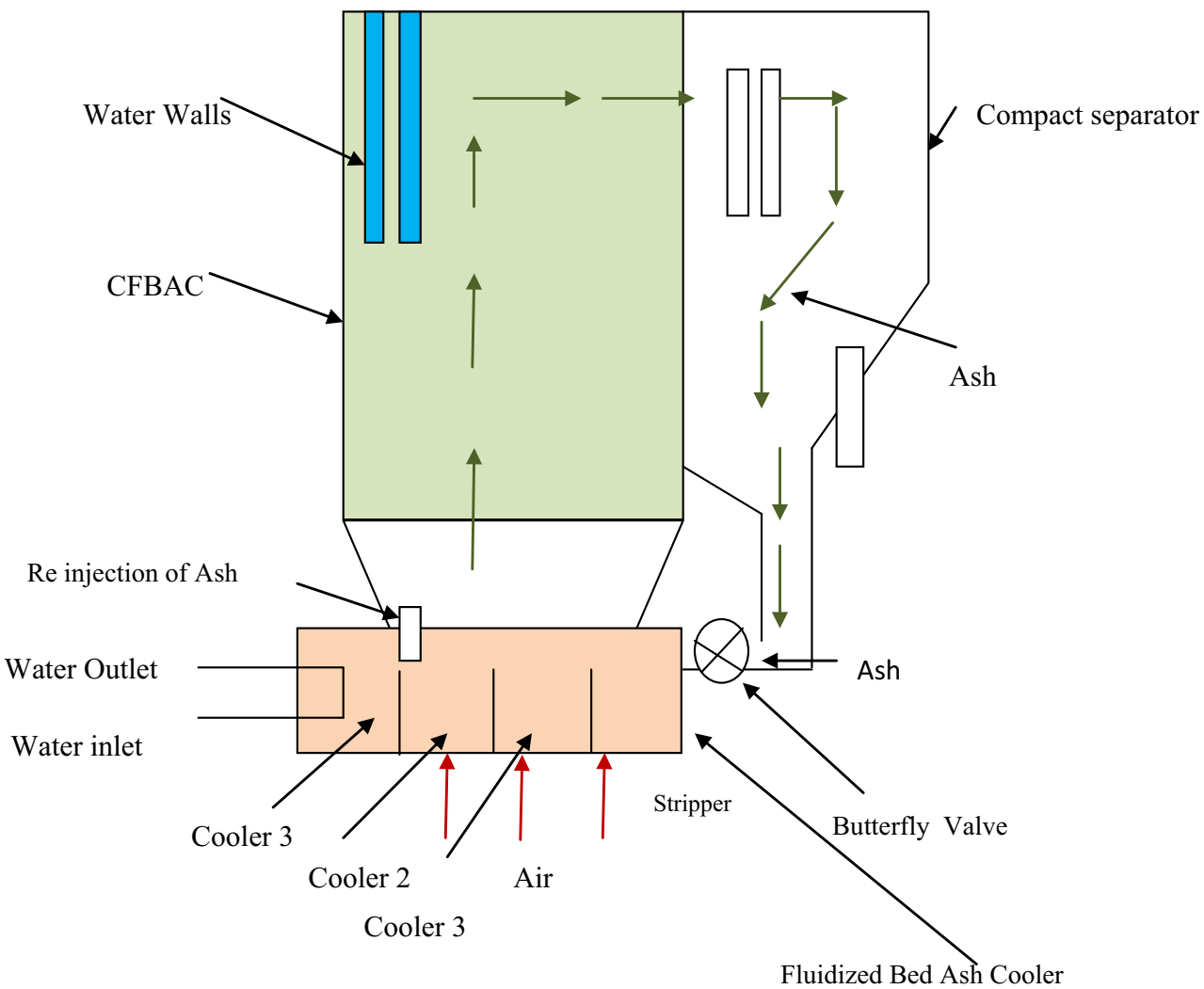


Table 1 LOI (Loss on ignition) numbers for bed drain

\begin{tabular}{lll}
\hline & LOI (design) & $\begin{array}{l}\text { LOI } \\
\text { (average over month) }\end{array}$ \\
\hline $\begin{array}{l}\text { Without agglomeration } \\
\text { in striper ash cooler }\end{array}$ & $1-1.5$ & $2.5-4$ \\
$\begin{array}{l}\text { With agglomeration } \\
\begin{array}{l}\text { With extreme agglomeration/ } \\
\text { shut down of unit }\end{array}\end{array}$ & $1-1.5$ & $5-6.5$ \\
Nil & Nil \\
\hline
\end{tabular}

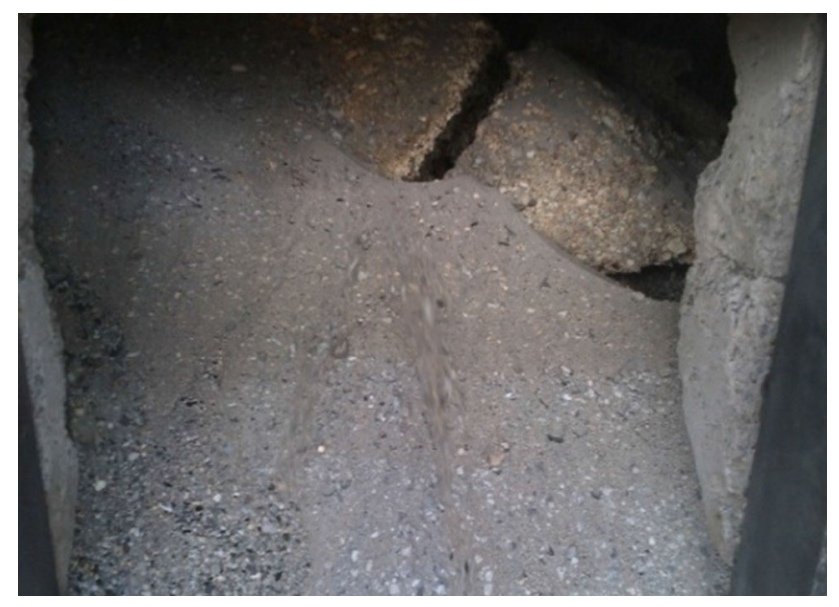

Fig. 2 Agglomerate seen in door of strip ash cooler

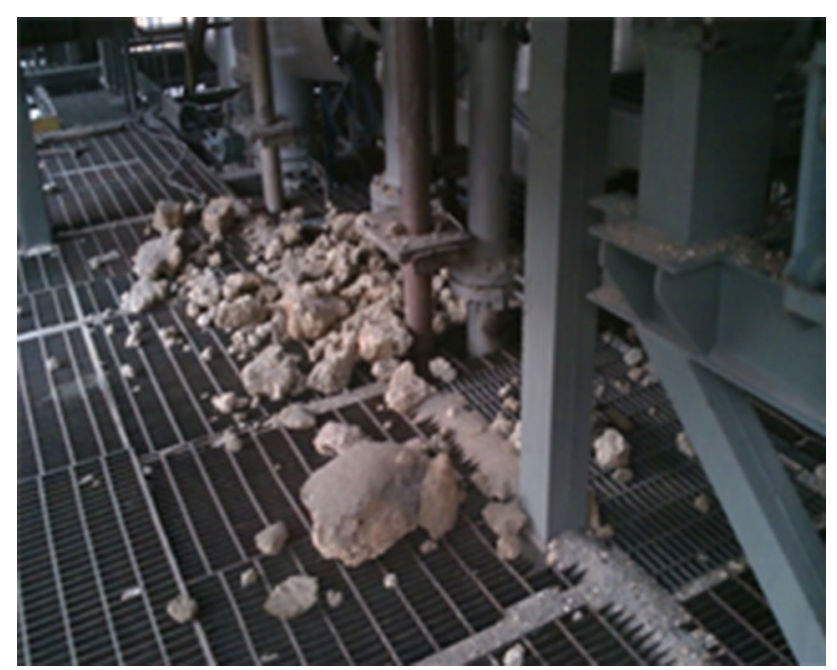

Fig. 3 Agglomerate seen outside the door of strip ash cooler

The agglomerate size varies in fluidized bed ash cooler from 10 to $50 \mathrm{~cm}$. The agglomerates at the door of fluidized bed ash coolers are shown in Fig. 2. The removed agglomerates from the strip ash coolers are shown in Fig. 3. The cause of the agglomerates formation in general

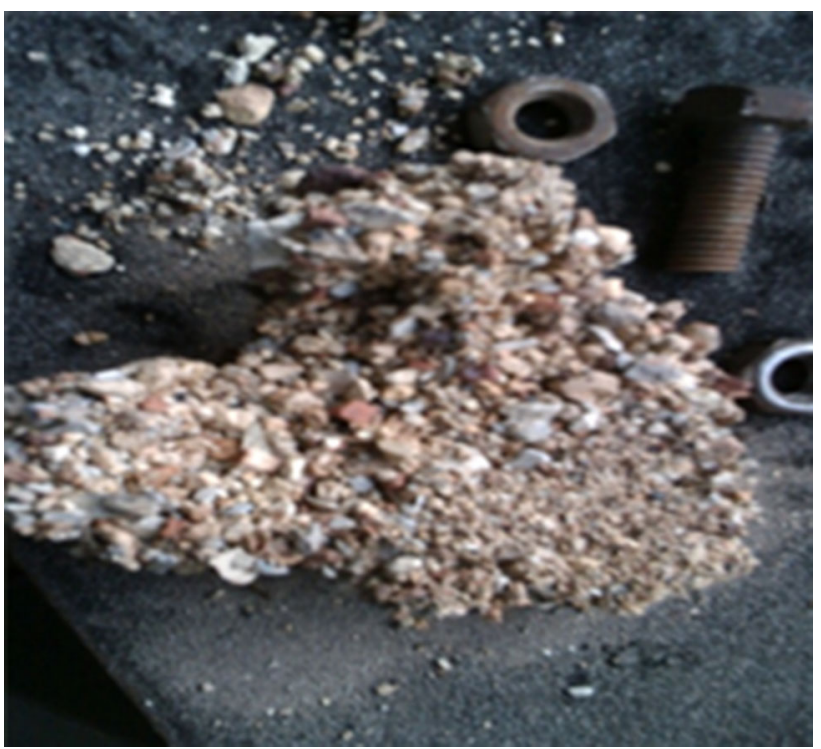

Fig. 4 Removed agglomerate lying at bottom during in operational strip cooler

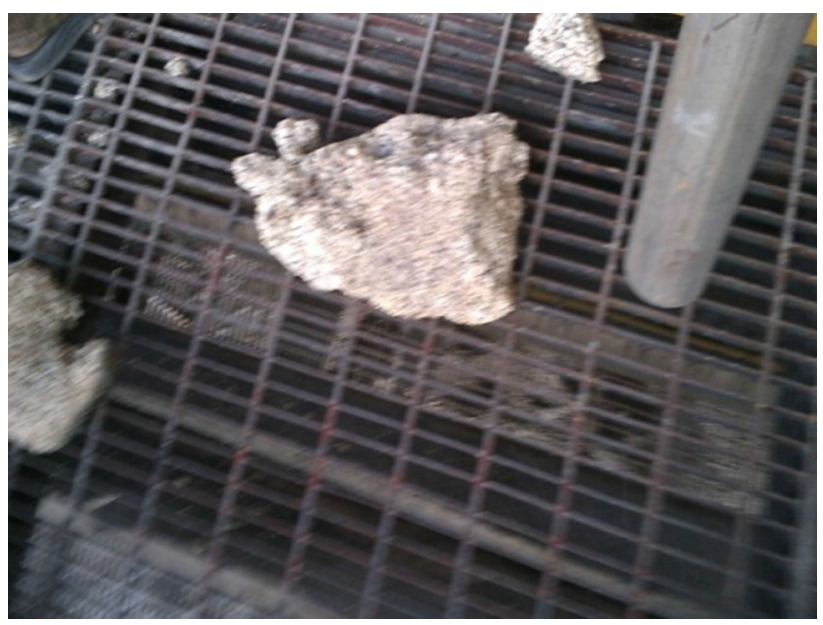

Fig. 5 Close up of agglomerate

in fluidized bed is resulted from molten ash sticking to bed material in the high temperature regions in the boiler.

Figures 4 and 5 shows the close up of clinkers in fluidized bed ash coolers. Table 2 shows the design and actual temperatures at different portions of the fluidized bed ash cooler. The operational temperature of fluidized bed ash cooler is given in Table 2 is much below the melting temperature of inorganic content present in ash. The fluidization velocities of stripper ash cooler unit is also given in Table 3. These are designed velocities as specified by designer. The Ash fusion temperature of ash is presented in Table 4. The plant was shut down for 5 days approximately in October 2012 with a daily loss of approximately Rs. 3.5 crore. The similar thing was done in the month of April with same estimated losses. 
Table 2 Design and actual temperatures of stripper ash cooler

\begin{tabular}{lllll}
\hline & Stripper & Cooler 1 & Cooler 2 & Cooler 3 \\
\hline Designed temperature $\left({ }^{\circ} \mathrm{C}\right)$ & $850-750$ & $600-500$ & $500-400$ & $400-350$ \\
Actual temperature $\left({ }^{\circ} \mathrm{C}\right)$ & 711 & 654 & 554 & 450 \\
\hline
\end{tabular}

Table 3 Fluidization velocities in stripper ash cooler

\begin{tabular}{ll}
\hline Fluidization velocity & Velocities \\
\hline Stripper & $1.2-1.6 \mathrm{~m} / \mathrm{s}$ \\
Cooler $1,2,3$ & $1-1.2$ \\
\hline
\end{tabular}

Table 4 Ash fusion temperature of different types of ashes

\begin{tabular}{lll}
\hline & Size fraction $(\mu \mathrm{m})$ & FDT $\left({ }^{\circ} \mathrm{C}\right)$ \\
\hline Silo bed ash & $100-150$ & 1450 \\
ESP fly ash & $50-80$ & 1370 \\
Silo fly ash & $40-70$ & 1375 \\
\hline
\end{tabular}

With above data and detail the focus of study was to find the causes of agglomeration in fluidized bed ash coolers and possible solutions to prevent agglomeration.

\section{Methodology Adopted in Project}

To check the causes of agglomeration in stripper ash cooler rigorous literature review, monitoring the plant for 3 months and various lab tests are performed at the plant site and at different laboratories across India. Samples of agglomerates, fuel, fly ash, bed drain material or original material has been collected to know the root causes of clinker (agglomerates) in strip ash coolers. Thermo gravimetric analysis (TGA) of coals used at plant site is also done. Size distribution of bed material/fuel is also done. Apart from above lab tests the operating conditions of furnace is checked during the focus period of study. The operating conditions of furnace is among one cause for agglomeration that is found.

\section{Literature Review}

Agglomeration i.e. clinker formation in riser of $\mathrm{CFB}$, bubbling fluidized bed, loop seal leg and stripper ash coolers is one of problem industry is facing. A lot many examples related to agglomeration/clinker formation in industrial fluidized bed units can found in literature [1-6]. Proper documentation of agglomeration in stripper ash cooler is rarely found in the literature [7]. Only few
Authors have highlighted [7] the problem of clinker formation in stripper ash cooler fluidized bed unit. Few authors have studied the stripper ash cooler at lab scale [8, 9] as well as industrial level [7, 10-13]. Zhang et al. [10] studied the fluidized bed ash cooler used in a CFB boiler. They found that influence of injected air on the transportation of ash is not significant. Roy and $\mathrm{Lu}$ [8] studied relationship of various parameters, such as the velocity of the fluidizing air, the bed pressure and the height of the static bed materials in each chamber of the BAC of CFB boiler. Bing Zeng [5] developed a novel fluidized bed ash cooler for CFB boilers. They found that fluidizing velocity and the height of the separation partition were two key parameters, which influenced the separation effect of the separation chamber. Lu and $\mathrm{Li}$ [11] studied cold model and experimental study on flow characteristics of bed material in fluidized bed ash cooler. The results shows that flow of bed material in ash cooler is dependent on pressure difference between CFB and fluidized bed the switch status of unlocking air, the structure of the exit of bubbling bed. Guo et al. [12] studied the cold model experiments and numerical simulation on a selective fluidized bed BAC in a 410t/h CFB boiler. They studied the flow behavior of ash in the unit. Park et al. [7] studied the characteristics of clinker formation in a CFB boiler firing Korean anthracite. They found that the amount of $\mathrm{Fe}$ and $\mathrm{Ca}$ in the fine particles of the ash plays a crucial role in the formation of agglomerates in the CFB boiler. Singh et al. [13] and Singh [14] found inorganic content in fuel plays important role in bubbling fluidized bed boilers. Ommen et al. [1] and Lee et al. [2]. found that poor fluidization due to the clinker formation may finally result in the complete defluidization of the bed, which means an unscheduled shutdown of the whole CFB boiler [1, 2]. Domestic Korean anthracite contains the many non-combustible constituents to form ash and has lower combustion efficiency compared to bituminous coal [3].

\section{Agglomerates and De-fluidization}

The agglomeration is defined as the phenomenon where particles gather into clusters of larger size than the original particles. The initial agglomeration temperature is defined as the temperature where the first molten phases appear that 
are able to glue bed particles together into agglomerates. Clinkers known as agglomerates in fluidized bed generally results from alkali compounds containing sodium, potassium and chlorides acting as catalysts bonding agents.

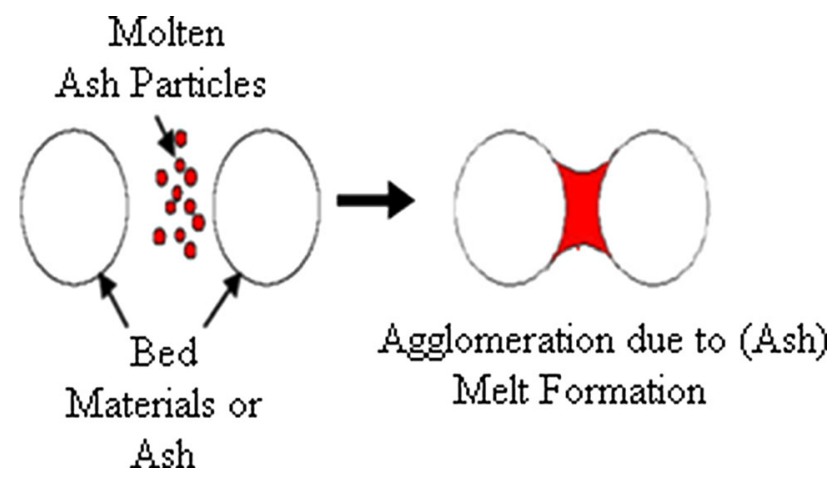

Fig. 6 Agglomeration of bed material after coating formation from gas phase

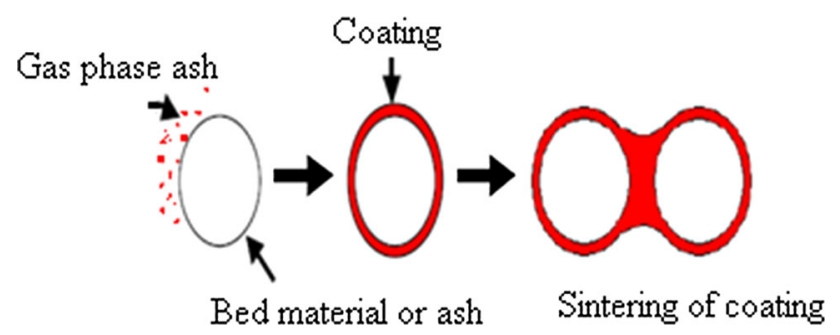

Fig. 7 Agglomeration of bed materials after melt formation of ash components
These alkali compounds volatilize at relatively low temperatures, such as those encountered during boiler operation [15] as shown in Fig. 6. Figure 7 also shows another theory of coating induced agglomeration [16]. The details of agglomeration mechanism could be referred from works of $[15,16]$. De-fluidization is defined as the total collapse of the fluidized bed resulting in a rapidly decreasing pressure drop or erratic behavior of the bed, which results in substantial temperature changes. The schematic summary of transformation of inorganic content is shown in Fig. 8. Agglomeration cannot only be explained by looking at physical phenomena, such as temperature, particle size distribution, mixing processes with resulting shear stresses between particles, and particle attrition, abrasion, fragmentation and cleavage, but also chemical phenomena will have to be taken into account.

The transformation of inorganic matter and agglomeration in fluidized bed is shown in Fig. 8. The majority of the agglomeration incidents at high temperature is induced by chemical reactions, from which cohesive particles are produced. It is well accepted that agglomeration in fluidized bed combustors or gasifiers is caused by generation of ash, which has a low melting temperature and interacts with bed materials. Thus, it is important to understand the ash transformation during combustion or gasification in a fluidized bed (Fig. 9).

The formation of ash with a low melting point is fuel dependent. Normally, ash from the fuels with a high content of alkali ( $\mathrm{K}$ and $\mathrm{Na}$ ) has a lower melting point [17].
Fig. 8 Schematic summary of the transformation of the inorganic matter and formation of agglomerates in fluidized bed combustion

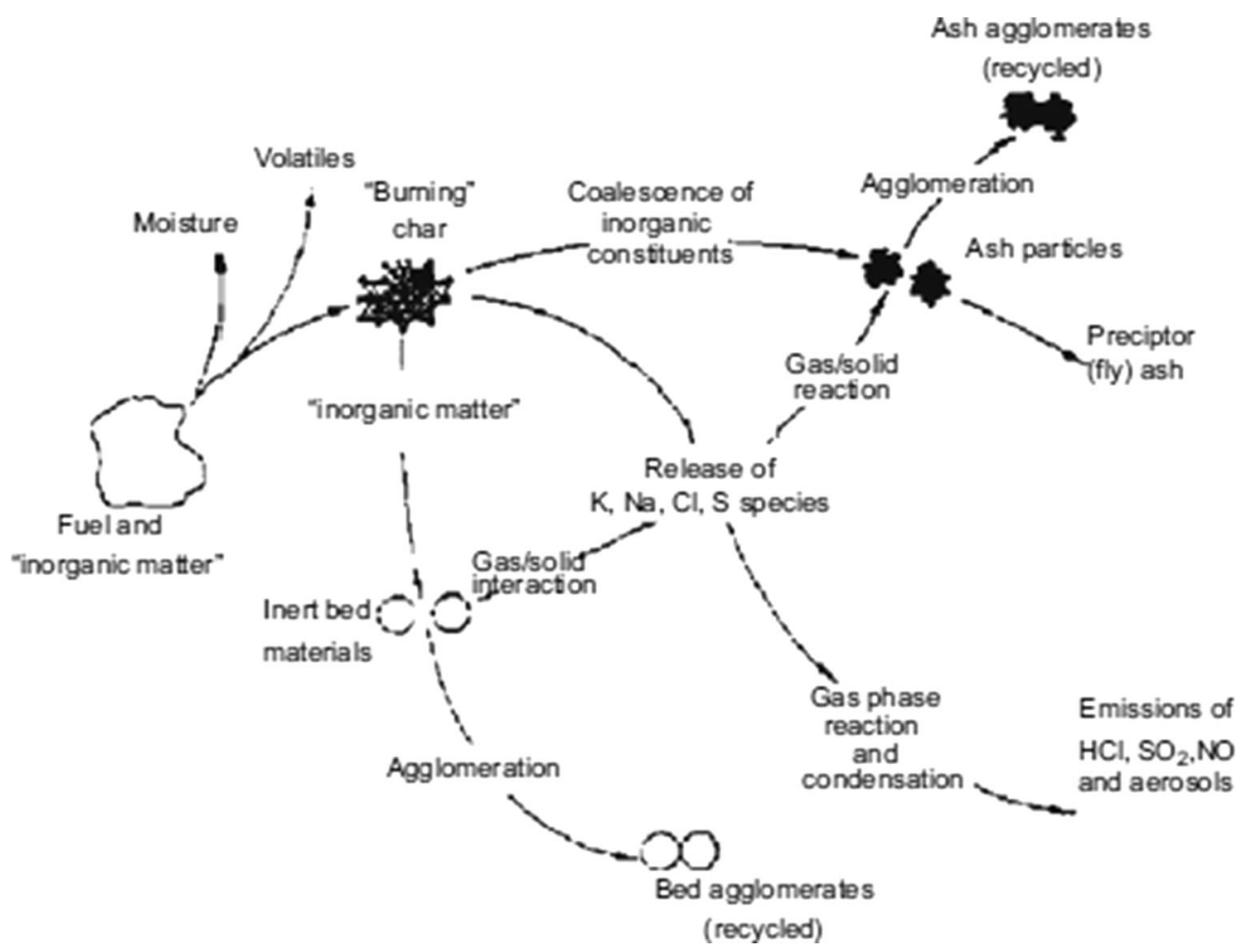


Fig. 9 Schematic bed segregation and defluidization process in a straw fired fluidized bed

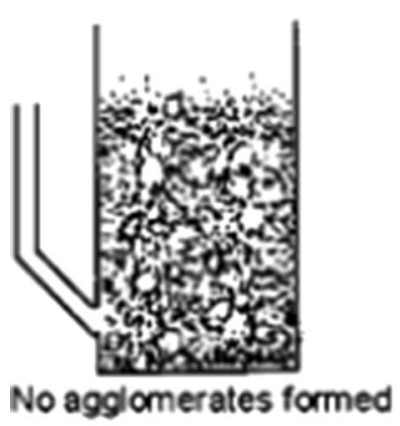

No agglomerates formed
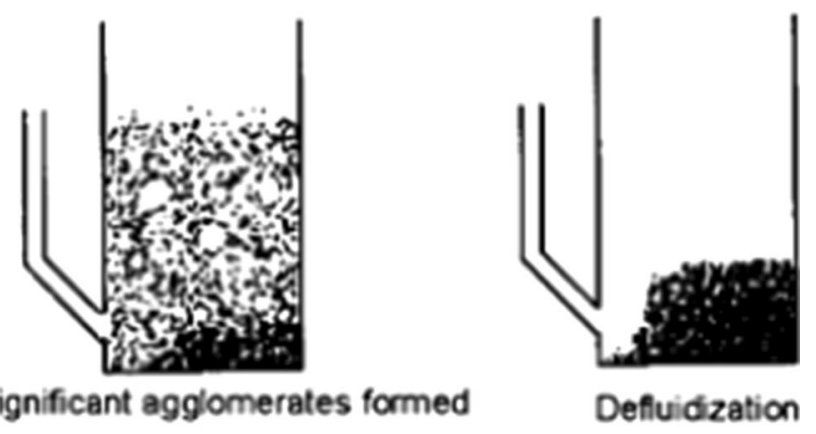

\section{Time}

Anthony et al. [3] examined the agglomerates in a petroleum coke-fired CFB boiler and revealed that both vanadium in the pet coke as well as calcium carbonate and calcium sulfate contribute to formation of the agglomerates. Singh et al. [18] found that inorganic content is one major reason behind agglomeration in biomass based power plant. Fuel ash interactions occur under normal fluidized bed combustion or gasification conditions and include the formation of molten silicates from sodium-, potassium-, calcium-, and sulfate-components and, possibly, solid-solid reactions [16]. Alkali containing compounds play a central role in both agglomeration processes in a fluidized bed. The mobility of alkali material is defined as its ability to come in physical contact with other materials [19]. It has been observed in biomass (especially the herbaceous biomass) fired fluidize beds that the bond of agglomerates is mainly composed of silicon and potassium, sometimes with a small amount of calcium [20-23], indicating that compounds consisting of $\mathrm{K}_{2} \mathrm{O}-\mathrm{SiO}_{2}$ and/or $\mathrm{K}_{2} \mathrm{O}-\mathrm{CaO}-\mathrm{SiO}_{2}$ are formed. The eutectic temperature of $\mathrm{K}_{2} \mathrm{O}-\mathrm{SiO}_{2}$ is as low as $770{ }^{\circ} \mathrm{C}$, and that of $\mathrm{K}_{2} \mathrm{O}-\mathrm{CaO}-\mathrm{SiO}_{2}$ is even lower [24], which is also lower than typical fluidized bed combustion temperatures of $800-850{ }^{\circ} \mathrm{C}$. The formation of molten silicates causes the particles to be adhesive. When alumina-rich compounds are present, the solid-solid reactions may result in formation of alkalialuminium silicates $\left(\mathrm{K}_{2} \mathrm{O}-\mathrm{Al}_{2} \mathrm{O}_{3}-\mathrm{SiO}_{2}\right)$, which have a much higher melting temperature. Gas-solid reactions may alter the composition of ash. The sulfur dioxide present if present in the gas phase at relatively low temperatures $\left(800{ }^{\circ} \mathrm{C}\right.$ ) will react with potassium forming $\mathrm{K}_{2} \mathrm{SO}_{4}$, which has a higher melting temperature than the eutectics of silicates [25].

In practice both physical and chemical phenomena will work together, leading to bed agglomeration or not. Figures 6 and 7 explain the process of agglomeration in fluidized bed. There are basically two different methodologies to explain the process. In first process as shown in Fig. 6 the agglomeration of bed material results from after coating formation from gas phase. In second process agglomeration of bed material results from melt formation of ash components. Both processes are possible in compact separators and fluidized bed ash coolers. Due to very high velocities in CFB the agglomeration is generally not possible in furnace. Ash sintering with the bed particles and is responsible for agglomerates. The same process is occurred during entering of ash in loop seals and fluidized bed ash coolers. The molten fine ash and inorganic oxides of minerals results in coalescing sand particles when entered in strip ash cooler which results in forming the agglomerates called clinkers in ash coolers.

\section{Inorganic Content in Fuel and Ash and Ash Fusion Temperature}

The fuel fed to furnace has significant effect on design and operation of CFB. To look the effect of fuel on the furnace, the eight samples collected from plant has been undergone elementary analysis of fuel at commercial laboratory, SGS Vishakhapatnam. The samples include coal, pure bed material, silo bed ash, ESP Fly ash, stripper clinkers, Silo fly ash, furnace drain material, stripper cooler drain material. The results of these ash forming elements is shown in Table 5. The final ash fusion temperature of different types of ashes is shown in Table 4. Most of the ash-forming elements will end up in the residual ash in the case of burning coal by the coalescence of the fused included minerals in coal during char burnout. The percentage of sodium and potassium content in fuel fed is quite low as found from there oxides mentioned in Table 5. The possibility of agglomeration (clinker) formation resulted from these is ruled out. Even the sulphur content is not very high, the possibility of $\mathrm{CaSO}_{4}$ is ruled out. It has been found from Table 5 that the percentage of silica and alumina in bed material is higher than manufactures design specification, but it 


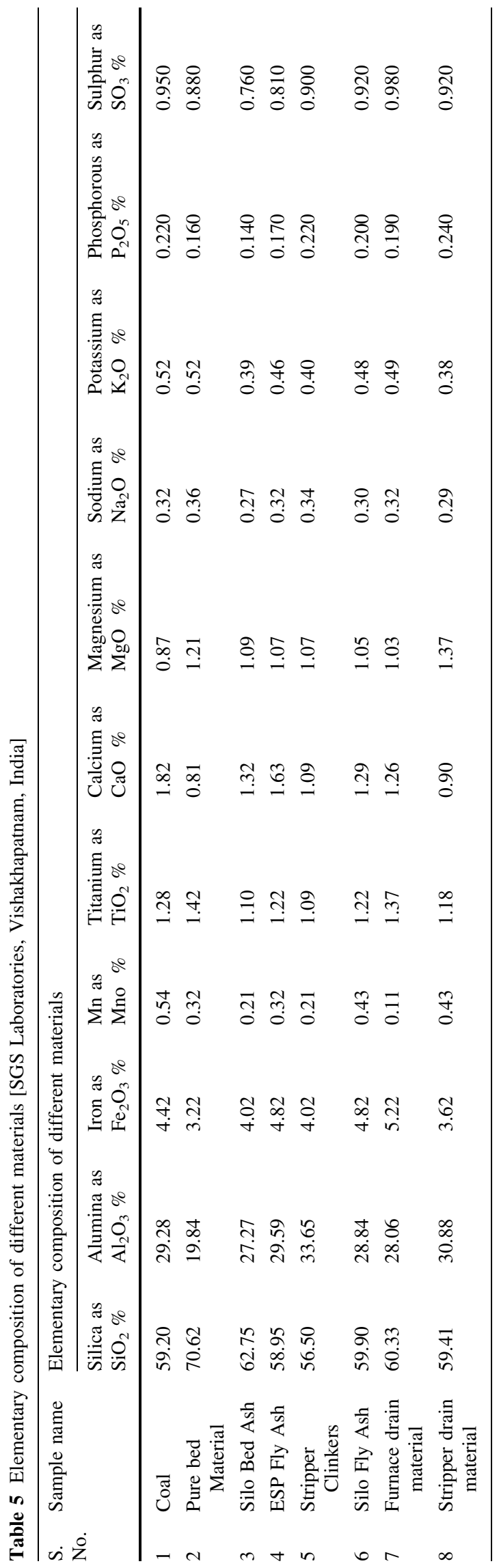

unlikely to enhance agglomeration phenomenon. The fate of following elements in CFB and fluidized bed ash cooler is discussed.

Silicon Silicon is present as silica $\left(\mathrm{SiO}_{2}\right)$ or various silicate minerals. The ash formed from them is mostly high in crystalline form. This kind of crystalline silicate ash does not cause slagging, fouling, sintering, or corrosion problems.

Aluminum Aluminum is present in many forms in coal. In the furnace processes they all form alumina, $\mathrm{Al}_{2} \mathrm{O}_{3}$. The alumina is relatively inert and having high melting point and unlikely to form agglomerates. But metallic Al likely to be melts around $600{ }^{\circ} \mathrm{C}$ and could easily form agglomerates. However the presence of metallic Aluminum as clear from Table 4 ruled out, as most of the Aluminum is in the form of $\mathrm{Al}_{2} \mathrm{O}_{3}$.

Iron Iron is present in various forms in the fuels. It is unknown whether $\mathrm{Fe}$ would cause similar fireside problems at the lower temperature conditions of a fluidized bed furnace. Thus it is assumed that iron oxide may be treated as inert compounds here. Generally presence of these oxides does not cause for agglomerates.

Potassium and Sodium The most important ash-forming element from a fireside problems point of view is potassium. Potassium is the root cause of bed sintering, fouling, and corrosion when using biomass based fuels and generally absent in Indian coals. Potassium is present in the fuel in different forms, and it is of vital interest to identify these forms. However, its concentration is typically low as cleared from Table 4 and it is unlikely to create problem of agglomeration.

Calcium The organic calcium compounds will be converted into calcium oxide. Calcium oxide has a low vapor pressure and a high melting point. At present there is no percentage of Limestone added and presence of most of it is in form of calcium oxide as clear from Table 4 . The presence of $\mathrm{CaO}$ likely to form $\mathrm{CaSO}_{4}$ which affects agglomeration process, however presence of $\mathrm{CaSO}_{4}$ is unlikely as shown in Table 4.

Magnesium Magnesium is chemically similar to calcium. It is also present as natural element in many biomasses/low concentrations in coal, but in much lower concentrations than calcium. In most cases $\mathrm{MgO}$ can be treated as an inert compound in combustion.

Sulfur In peat and coals part of the sulfur may be present as inorganic minerals. Pyritic $\left(\mathrm{FeS}_{2}\right)$ sulfur is effectively released in a complex decomposition process and will finally form $\mathrm{SO}_{2}$. In summary, most of the sulfur in fuels will be released in combustion and finally yield $\mathrm{SO}_{2}$. The 
only significant exception is calcium sulfate, which may be present in some fuels.

Mn, Titanium and Phosphorus The compounds of these are having no known effects of agglomeration. Similarly the release and fate of the various phosphorus compounds does not appear to cause agglomeration/sintering problems.

Ash Fusion Temperature The final ash fusion temperature of ashes from plant is higher than melting temperatures of various ash compounds. The Ash fusion temperature of different types of ashes is shown in Table 4.

The temperature inside the stripper ash cooler is not high enough. The design temperature and actual temperature inside the stripper ash cooler is shown in Table 4 . The Ash fusion inside the stripper ash cooler responsible for agglomeration inside fluidized bed ash cooler is ruled out.

\section{Operational Problems}

The plant was monitored for about 3 months to look the causes of clinker formation. The various operational problems are discussed as following. Figure 10 shows the Agglomeration Process inside CFB boiler unit that is responsible for in operation of stripper ash cooler. The agglomeration is started in compact separator and by the time it reaches the stripper ash cooler bigger agglomerates are formed. The following sections deals with operating conditions that leads to agglomeration.

\section{Higher Temperature Resulting from Fuel Composition and Supply of Coal}

Proximate analysis of fuel is checked consecutively for many months during year. The few sample results of August and October, 2012 are provided in Table 6. The full year data is not shown in this text due to bulk volume. The proximate analysis specifies components such as cyclone and later down flow equipment during designing. It is found from the data provided by plant people that percentage of ash in some lots is higher than specified design and volatile matter is some lots is quite lower than designer limit. The low volatile matter and high ash content as clear from Table 6 leads to high furnace temperature and compact separator as quite big percent of fuel is likely to be burned in cyclone (compact separator). The compact separator temperature is shown in Table 8. It is also found that on some days the fixed carbon content is higher and gross calorific value of supplied coal is quite higher than designed value. It is also found that during this time period the supply of coal fed to furnace through coal feeder is same. This phenomenon leads to increase the temperature of furnace or compact separator causing the initiation of clinkers (agglomerates) formation. These agglomerates lie dormant in furnace in dead zone, loop seals and stripper coolers. Agglomeration is one such process which one started it continues until prevented. Due to pressure and force of passing material continuously and these small
Fig. 10 Flow chart of agglomeration process inside circulating fluidized bed boiler unit

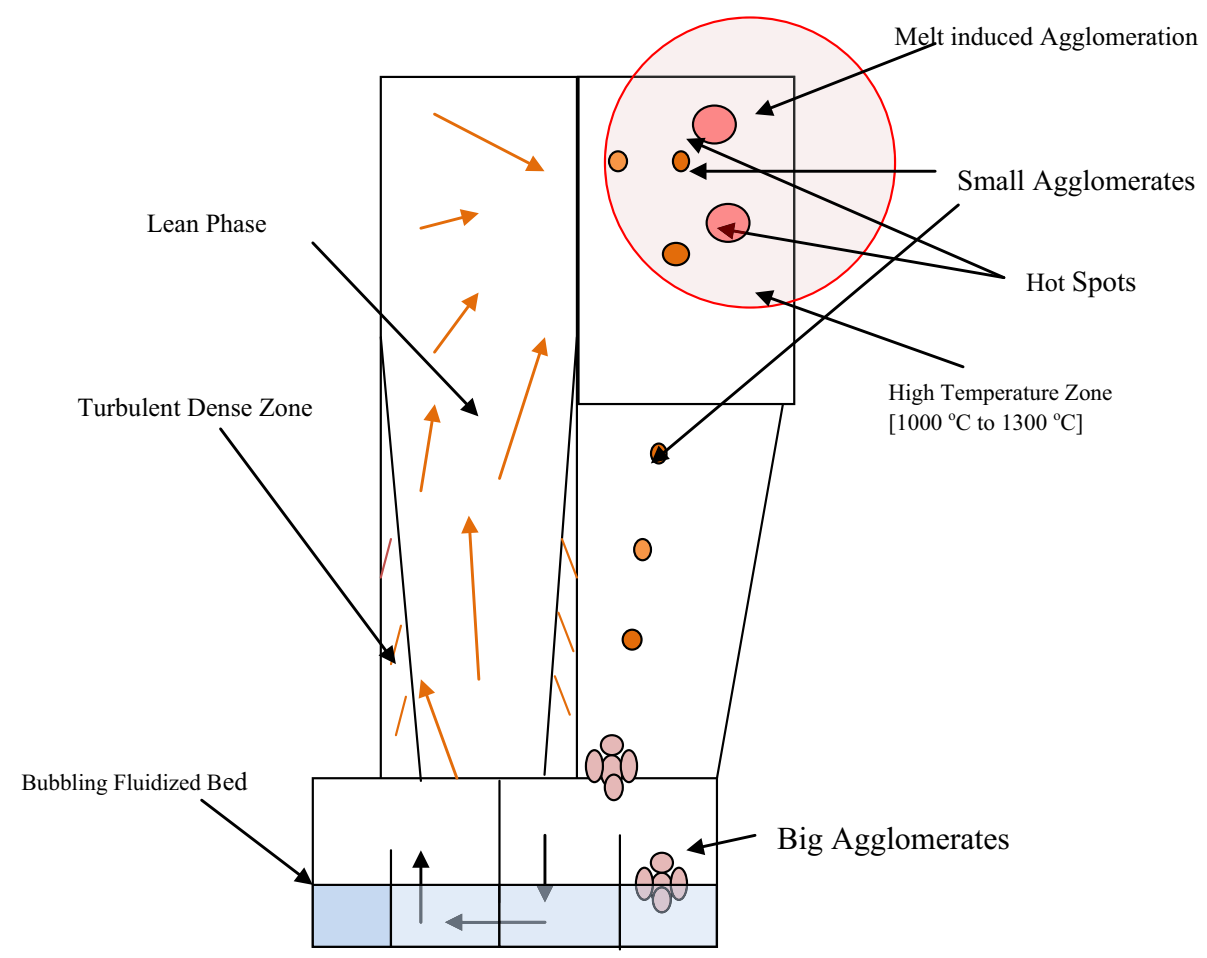


Table 6 Proximate analysis of fuel

\begin{tabular}{|c|c|c|c|c|c|}
\hline Coal samples (montly/year database) & Moisture & Ash & Volatile & Fixed carbon & $\overline{\mathrm{C} . \mathrm{V} \mathrm{KCal} / \mathrm{kg}}$ \\
\hline 9-Aug-12 & 16.94 & 38.41 & 14.2 & 44.55 & 4515 \\
\hline 17-Aug-12 & 16.88 & 40.11 & 9.98 & 47.11 & 4435 \\
\hline 20-Aug-12 & 17.38 & 39.60 & 9.33 & 48.51 & 4440 \\
\hline 25-Aug-12 & 12.76 & 40.66 & 9.17 & 47.83 & 4456 \\
\hline 12 Oct 2012 & 9.97 & 41.39 & 17.64 & 38.01 & 4368 \\
\hline 17 Oct 2012 & 9.47 & 44.86 & 15.27 & 37.22 & 4166 \\
\hline 24 Oct 2012 & 8.79 & 43.61 & 12.61 & 41.33 & 4180 \\
\hline 27 Oct 2012 & 11.11 & 41.87 & 13.04 & 41.10 & 4308 \\
\hline
\end{tabular}

agglomerates could leads to big agglomerates. These could lead to bigger agglomerates in the stripper ash coolers.

\section{Size Distribution of Fuel and Bed Material}

\section{Size Distribution of Fuel}

It is found that the size distribution of fuel is quite different than manufacturer a specification in many lots than which is fed to boiler. Sieve analysis of coal from drag chain feeder analyzed and checked. It is noted for the month of August and October 2012. It is found that on some days on which size distribution of coal is supplied less than $200 \mu \mathrm{m}$. The percentage of this size may go up to $15 \%$ on few days. As per designer percentage of these particles less than $200 \mu \mathrm{m}$ should not be more than $5 \%$. Since the feeding of fuel is done over bed, particles smaller than $200 \mu \mathrm{m}$ exert the greatest negative influence on the combustion; as these particles are entrained instead of reaching the bed surface and will burn during it trajectory or likely to burn near top of furnace or in compact separator. As evident from Table 6 the volatile matter in some lots is lower on some days than specified limit, so some particles burn in compact separators because the of higher velocities in CFB. This leads to high temperature in compact separators. and hot spots in compact separators.

The temperature in these cases sometimes could be higher than final ash fusion temperature of coal and temperature of oxides formed as a result of combustion. The final ash fusion temperature of ashes is given in Table 4. It leads to start formation of agglomerates (clinkering) in compact separators, loop seals and ultimately which reach the fluidized bed ash coolers. The description of whole process is shown in Fig. 10. The particle with size less than $200 \mu \mathrm{m}$ will produce more fine ash, which likely to have more sintering tendency than ash produced from particles having size more than $200 \mu \mathrm{m}$. The particles supplied/fed are greater than $8 \mathrm{~mm}$ size as limit specified by designer on many days. These particles are not getting sufficient time for complete burn out and the residence time of these particles is low. The tendency of burning fine char of these particles at a later stage in compact separators causing increase of temperature in compact separators (cyclones) than expected, resulting in higher temperature in compact separators, which is causing startup of clinker formation there and which are passed to return leg, loop seal and stripper cooler.

\section{Size Distribution of Bed Material}

Due to combustion process the size of bed material increases. The composition of bed material will change with the combustion of coal. The original size distribution of sand are given as $100 \%<600 \mu \mathrm{m}, 75 \%<250 \mu \mathrm{m}$, $50 \%<180 \mu \mathrm{m}, 25 \%<130 \mu \mathrm{m}$. Table 7 shows particle size distribution of bed material and the sieve analysis percentage by mass of bed material. The size distribution of bed material after 1 week operation and during shut of stripper ash cooler is shown in Table 7. The normal tendency of the sized bed particle is to increase after combustion and gasification. It has also been found that after 1 week and during shut down of strip ash cooler the size of particles and percentage of bigger agglomerates increased drastically. Once the agglomeration is initiated, the size increases drastically.

\section{Thermo Gravimetric Analysis of Coal}

Thermo gravimetric analysis of all three coals is carried out. The heating rate is $40{ }^{\circ} \mathrm{C}$ and it has been done on Perkin Elmer TGA 6. The TGA of coals used at plant site is shown in Fig. 11. The percentage weight lost for Grade D coal is higher than Grade F coal. The TGA has been done to look down the certain characteristics of three coals used at site. But no conclusive evidence is found about agglomeration in strip ash coolers from the thermo gravimetric analysis. 
Table 7 Particle size distribution of bed material during different intervals

\begin{tabular}{lccc}
\hline Screen size & $\begin{array}{l}\text { Sieve analysis, \% by mass } \\
\text { (USING IS: Sieve) (normal operation) }\end{array}$ & $\begin{array}{l}\text { Bed Ash (1 week } \\
\text { operation) samples }\end{array}$ & $\begin{array}{l}\text { Bed ash (during shut down } \\
\text { of stripper ash cooler) }\end{array}$ \\
\hline$+4.75 \mathrm{~mm}$ to $+25 \mathrm{~mm}$ & 15.24 & 20.21 & 26.1 \\
$-4.75 \mathrm{~mm}$ to $2.36 \mathrm{~mm}$ sieve & 7.42 & 9.1 & 13.2 \\
$-2.36 \mathrm{~mm}+1.18 \mathrm{~mm}$ sieve & 4.06 & 8.5 & 9.1 \\
$-1.18 \mathrm{~mm}+600$ micron sieve & 3.17 & 6.3 & 8.7 \\
-600 micron +300 micron sieve & 21.79 & 27.1 & 30.1 \\
-300 micron +150 micron sieve & 32.91 & 25.2 & 9.1 \\
-150 micron +75 micron sieve & 13.30 & 3.2 & 3.1 \\
-75 micron +63 micron sieve & 1.77 & 0.7 & 0.4 \\
-63 micron sieve & 0.34 & 0.1 & 0.2 \\
\hline
\end{tabular}

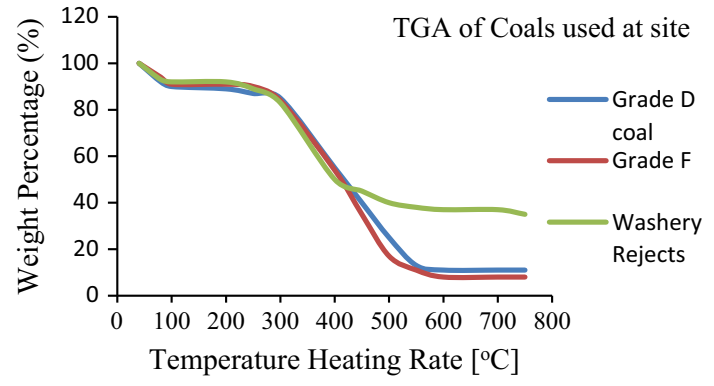

Fig. 11 Thermo gravimetric analysis (TGA) of coals used at Site

\section{Solution to Clinker (Agglomeration) Formation}

The solution to this problem is tricky as the supply of coal form mine contains more fines, which produces more fine ash and likely to sinter because of higher temperature in compact separator. The solution lies in maintaining the lower temperature in compact separator than furnace or as per design values provided by manufacturer.

\section{Furnace and Compact Separator Temperature}

Furnace temperature can be controlled by changing the solids loading in the upper furnace by varying the primary/ secondary air ratio. The temperature in the combustion chamber can vary under the influence of fuel particle size, volatile matter and fuel moisture content and heating value, the height of the bed in the lower part of the combustion chamber, primary to secondary air ratio, and excess of supplied air. The parameter which has significant influence on formation of uniform temperature profile along the height of the combustion chamber is solids hold-up in the combustion chamber. The stream of bed material and gas in the combustion chamber serves a number of other important functions, such as absorbing heat from the lower part of combustion chamber to keep the temperature in this zone around $850{ }^{\circ} \mathrm{C}$, transferring heat to the heating surfaces located in the combustion chamber, (exchange of heat by convection of particles plays a fundamental role in transfer of heat in the combustion chamber), and influencing gas/particle mixing which also leads to higher residence time in the combustion chamber. The degree of internal circulation of the bed material, i.e. distribution of particles in the volume of the combustion chamber and the degree of external circulation of the bed material between combustion chamber and the return system, is also an important factor. As per Table 8 and specifications provided by designer, the temperature inside compact separator should be lower than furnace. Whereas actual data measured from the plant this temperature is $100-150{ }^{\circ} \mathrm{C}$ higher since the installation of unit takes place. The temperature inside the compact separator must be lower than furnace or it should match as per Table 8 to decrease the agglomeration/ash sintering/clinker formation phenomenon. To control the compact separator temperature, the amount of fines in coal and particles greater than $8 \mathrm{~mm}$ should be controlled as per designer value. If in some lot the percentage of fines increases then supply of primary air to furnace should be decreased considerably.

\section{Discharging of Bed Ash/Drain Bed Material from Fluidized Bed Stripper Ash Coolers}

Proper cleaning and removing bigger particles from furnace is required for proper working of strip ash cooler. Stripper bed pressure is indicating the quantity of accumulated ash in the cooler 3 chamber. When bed volume increases, the bed pressure increases accordingly. During formation of agglomeration bed drain should be increased. The ash cooler which is operational should be cleaned periodically. The particles bigger than five $\mathrm{cm}$ in size should be removed periodically by visually inspection after opening the door. It should be cleaned twice during interval of $24 \mathrm{~h}$ after opening the door. 
Table 8 Temperature profile of furnace specified by designer and actual values

\begin{tabular}{lllllll}
\hline $\begin{array}{l}\text { Gas temperature } \\
\text { profile }\left({ }^{\circ} \mathrm{C}\right)\end{array}$ & $\begin{array}{l}100 \% \text { grade } \\
\mathrm{D} \text { coal }\end{array}$ & $\begin{array}{l}100 \% \text { grade } \\
\mathrm{F} \text { coal }\end{array}$ & $\begin{array}{l}80 \% \text { grade } \mathrm{D}+20 \% \\
\text { washery rejects }\end{array}$ & $\begin{array}{l}80 \% \text { grade } \mathrm{F}+20 \% \\
\text { washery rejects }\end{array}$ & $\begin{array}{l}\text { Present avg. } \\
\text { operating temp. }\left({ }^{\circ} \mathrm{C}\right)\end{array}$ & $\begin{array}{l}\text { Hot spots } \\
\text { temperature }\left({ }^{\circ} \mathrm{C}\right)\end{array}$ \\
\hline $\begin{array}{l}\text { Furnace outlet } \\
\text { Compact sep. }\end{array}$ & 897 & 880 & 887 & 875 & $900-1000$ & 1365 \\
$\quad$ outlet & 875 & 859 & 869 & 858 & $925-1000$ & 1370 \\
\hline
\end{tabular}

Table 9 Designer data for supply of primary air at $47{ }^{\circ} \mathrm{C}$

\begin{tabular}{lcccc}
\hline Cold primary air & stripper cooler 1 (a) Kg/h & stripper cooler 1 (b) & stripper cooler 1 (c) & stripper cooler 1 (d) \\
\hline Maximum & 1100 & 1497 & 4724 & 4724 \\
Normal & 1000 & 1361 & 4294 & 4294 \\
Minimum & 300 & 408 & 1288 & 1288 \\
\hline
\end{tabular}

\section{Sizing and Blending of coal}

Proper coal sizing is one of the key measures to ensure efficient combustion and uniform temperature across compact separators. The sizing of coal should be maintained as per designer data mentioned which some time is not done presently. In case of coal lots having excessive fines, it is advisable to blend the predominantly lumped coal with lots containing excessive fines. Coal blending may thus help to limit the extent of fines and maintaining proper size in coal being fired to furnace.

\section{Supply of Primary Air to Different Compartments in Ash Cooler}

There are four compartments in this ash cooler. All the compartments are fluidized beds. The flow of ash is towards the last cooler (cooler 3) from stripper, the last cooler is cooled by water and fluidizing air. The ash is cooled with water in last chamber. The fine particles are stripped of ash and passed to furnace. Table 9 shows the designer data for the supply of primary air at $47{ }^{\circ} \mathrm{C}$. Higher fluidization velocities always lower the tendency for agglomeration and deposition problems because of already mentioned between particle adhesion and friction forces. In some cases it has been seen that agglomerates already formed can be disintegrated by temporarily increasing the gas velocity. Increasing the gas velocity may also work in negative direction. This is when the agglomerates are stronger and settlement on the base of fluidized bed already pronounced. Strong and slowly settling agglomerates are more typically formed in lower temperature range. Increasing the gas velocity in primary zone may also worsen the situation by reducing the bulk density in still fluidized areas adjacent to agglomerates and reducing the buoyant forces on agglomerates. To decrease the agglomeration the primary air supplied to stripper cooler chamber should be controlled in systematic manner. To maintain the uniform temperature in ash coolers the supply of air to stripper cooler should be maintained uniformly. The velocities of air should supplied as per Fig. 12a-d and with respect to Table 9 .

\section{Supply of Primary air and Secondary Air to furnace}

The ratio of primary and secondary should be controlled to control the temperature of furnace. These values should be controlled as per the quality of fuel supplied. At present it is adjusted as per hit and trial method. The value of PA should be adjusted w.r.t size of coal or designer data. It should be decreased when size of coal less than $0.2 \mathrm{~mm}$, which will allow increasing the residence time of coal particles in furnace, allowing them to burn in deep furnace.

\section{Supply of Air to Wall Seal Blower}

The recycle system moves the soilds from the low pressure cylone to the high pressure bottom of the furnace or riser. The sintering/agglomeration could happen in loop seals if there are pockets of less fluidized soilds and the temperature of the solids is above $900{ }^{\circ} \mathrm{C}$. Supply of air to wall seal blower is having no effect of formation of agglomerates, but careful supply of air can influenece the dis integration of small agglomerates.

\section{Bed Particle Management of Strip Ash Cooler and Bed Material Additives}

The fluidizing velocity is relative to the particle size distribution (PSD) and the density of the solids. The 
Fig. 12 Block diagram of stripper section

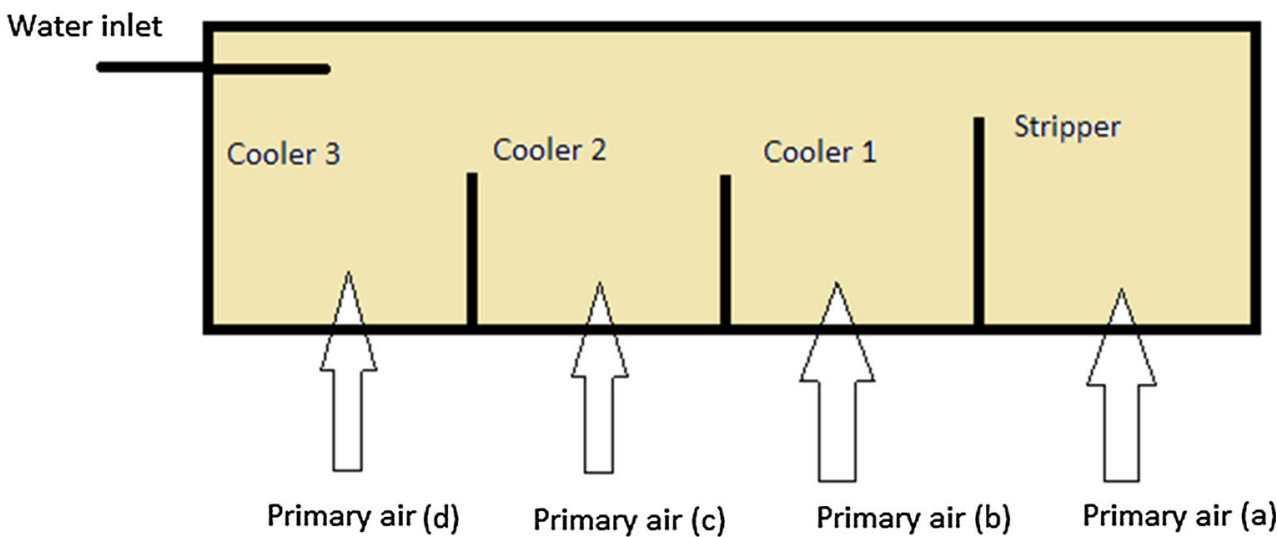

fluidizing air is and fluidizing velocity is directly influenced by the operational bed temperature. The PSD of the bottom ash of the boiler critically affects normal FBAC operation. Sieve analysis for drain bed material analysis should be performed on daily basis. Present practice is done on random basis. As soon as the small and large agglomerate (clinker) formation is started in stripper cooler, the fresh material needs to be added periodically. The sieve analysis of bed material needs to be done for replacement of bed material on daily basis. When size distribution of $15 \%$ of bed material is greater than $4.75 \mathrm{~mm}$, it is time to replace at least $20 \%$ of sand with fresh/cleaned sand into the bed. To avoid the cost of fresh bed material the sand should be cleaned periodically. The renewable of fresh/cleaned bed material could be optimized by careful noting the percentage of big rocks in drained bed material.

It is found from Table 4 that there is no alkali related compounds present in elementary analysis of coal and coal ash, so no additives like kaolin are required in plant.

\section{Conclusions}

From the above study following conclusion are made.

1. Clinker formation(Agglomeration) in strip ash coolers results from due to physical/chemical properties of coal and operating conditions. The physi$\mathrm{cal} / \mathrm{chemical}$ property of coal and operating conditions leads to high temperature in compact separator. This high temperature in compact separator results in sintering of fine ash as the supply of coal in various lots is not matching designer values. This sintering/molten ash results in formation of agglomerates during it way to loop seals and stripper cooler. Controlling temperature of compact separators would result in decrease of agglomerate formation inside the strip ash coolers.
2. To decrease the agglomerates formation in stripper coolers, the primary air supplied to stripper cooler chamber should be controlled in systematic manner.

3. The formation of small agglomerates should be avoided by checking particle size distribution of bed material and adding fresh or cleaned bed material and during agglomeration, the two ash coolers RHS and LHS, should be used alternatively. The visually inspection and cleaning of stripper ash cooler should be done after every $12 \mathrm{~h}$.

Acknowledgments The author is thankful to BLA power, Newari, Madhya Pradesh, India for granting permission to conduct research. The author is also thankful to Incessant Energy Technologies Ludhiana, India for sponsoring ten percentage of grant for research.

\section{References}

1. J.R. Ommen, Monitoring fluidized bed hydrodynamics, Ph.D. Thesis, Delft University Press, Netherlands, 2001

2. J.-M. Lee, D.-W. Kim, J.-S. Kim, J.-J. Kim, Poor fluidization phenomena and detection in the FBAC of the Tonghae CFB boiler. J. Chem. Eng. Jpn. 41, 710-715 (2008)

3. D.W. Kim, J.M. Lee, J.S. Kim, J.J. Kim, Co-combustion of Korean anthracite with bituminous coal in a circulating fluidized bed combustor. Korean J. Chem. Eng. 24(3), 461-465 (2007)

4. W. Lin, K. Dam-Johansen. Sintering in biofuel and coal-biofuel fired FBC, Final report to EC Joule III, Department of Chemical Engineering, Technical University of Denmark, 1997

5. E.J. Anthony, L. Jia, F. Preto, A.P. Iribarne, J.V. Iribarne, Agglomeration and fouling in petroleum coke fired boilers, 32nd IEA FBC Conversion Meeting, Gothenburg, Sweden, 27-30 June 1996

6. S.A. Benson, E.A. Sondreal, J.P. Hurley, Status of coal ash behavior research. Fuel Process. Technol. 44(1-3), 1-12 (1995)

7. H.J. Park, N.H. Jung, J.M. Lee, Characteristics of clinker formation in a circulating fluidized bed boiler firing Korean anthracite. Korean J. Chem. Eng. 28(8), 1791-1796 (2011)

8. R.S. Amanol, X. Lu, Improvement of fluidized bed bottom ash cooler performance in CFB boiler, in Proceeding of the First International Energy 2030 Conference, Abu Dhabi, UAE, 2006

9. B. Zeng, X. Lu, L. Gan, M. Shu, Development of a novel fluidized bed ash cooler for circulating fluidized bed boilers: 
experimental study and application. Powder Technol. 212, 151-160 (2011)

10. Z. Man, B. Rushan, X. Qinggui, Fluidized bed ash cooler used in a circulating fluidized bed boiler: an experimental study and application. Powder Technol. 201, 114-122 (2010)

11. X.F. Lu, Y.L. Li, A cold model experimental study on the flow characteristics of bed material in a fluidized bed bottom ash cooler in a CFB boiler. J. Therm. Sci. 9(4), 381-384 (2000)

12. T. Guo, X.F. Lu, H.Z. Liu, Cold model experiments and numerical simulation on a selective fluidized bed bottom ash cooler in A 410t/H CFB boiler, in Proceedings of 19th International Conference on Fluidized Bed Combustion, Vienna, Austria, 2006.

13. R.I. Singh, S.K. Mohapatra, D. Gangacharyulu, Study of agglomeration in $3.5 \mathrm{MW}$ AFBC using rice husk particles. Int. J. Renew. Energy Technol. 2(2), 120-142 (2011)

14. R.I. Singh, Study of fluidized bed combustion power plant using agri residues. Appl. Therm. Eng. 71(1), 616-626 (2014)

15. B.J. Skrifvars, M. Hupa, A. Moilanen, R. Lundqvist, Characterization of biomass ashes, in Application of Advanced Technology to Ash Related Problems in Boilers, 1996, pp. 383-398

16. R.W. Bryers, Fireside slagging, fouling and high temperature corrosion of heat transfer due to impurities in steam raising fuel. Prog. Energy Combust. Sci. 22, 29-120 (1996)

17. A.R. Manzoori, E.R. Lindner, P.K. Agarwal, Inorganic transformation during the circulating fluid bed combustion of low-rank coals with high content of sodium and sulphur. in Proceedings of the Engineering Foundation Conference on Inorganic Transformations and Ash Deposition During Combustion, Palm Coast, Florida, USA, 10-15 March, 1991, p. 735-762
18. R.I. Singh, S.K. Mohapatra, D. Gangacharyulu, Studies in an atmospheric bubbling fluidized-bed combustor of $10 \mathrm{MW}$ power plant based on rice husk, Energy Convers. Manag. 49(11), 3086-3103 (2008)

19. L.L. Baxter, T.R. Miles, T.R. Miles, B.M. Jenkins, T. Milne, D. Dayton et al., The behavior of inorganic material in biomass-fired power boilers: field and laboratory experiences. Fuel Process. Technol. 54(1-3), 47-78 (1998)

20. D. Salour, B.M. Jenkins, M. Vafaei, M. Kayhanian, Control of inbed agglomeration by fuel blending in a pilot scale straw and wood fueled AFBC. Biomass Bioenergy 4(2), 117-133 (1993)

21. M. Ö hman, A. Nordin, B.-J. Skrifvars, R. Backman, M. Hupa, Bed agglomeration characteristics during fluidized bed combustion of biomass fuels. Energy Fuels 14(1), 169-178 (2000)

22. W. Lin, K. Dam-Johansen, F. Frandsen, Agglomeration in biofuel fired fluidized bed combustors. Chem. Eng. J. 96(1-3), 171-185 (2003)

23. H.J.M. Visser, S.C. van Lith, J.H.A. Kiel, Biomass ash-bed material interactions leading to agglomeration in FBC. in Proceedings of the 17th International Conference on Fluidized Bed Combustio, 2003, paper 150. New York, USA: ASME, 2003

24. E.M. Levin, C.R. Robbins, H.F. McMudie, Phase Diagrams for Ceramists, vol. 1. (The American Ceramic Society, Inc., 1964), p. 87

25. W. Lin, K. Dam-Johansen, Sulphur capture by alkali content of straw during co-firing with coal in FBC, in B.Q. Li, Z.Y. Liu Prospects for Coal Science in the 21st Century, 1999, p. 1421-4 